\title{
PHYSIOLOGICAL CHARACTERISTICS OF CARNIOLAN AND ITALIAN HONEY BEE STRAINS WITH SPECIAL REFERENCE TO CITRUS HONEY COMPONENTS IN EGYPT
}

\author{
Amany S. M. Abou-Lila \\ Beekeeping Res., Dep., Plant Protection Res., Inst., ARC., Dokki- Giza - Egypt
}

Received: Jul. 2, 2016

Accepted: Jul. 18, 2016

\begin{abstract}
Studies some of physiological properties on honey bee workers in both Carniolan and Italian pure strains in Order to reach a physiological method to differentiate between both strains and citrus honey reproduce from them with showed of DNA analysis of both strains by (PCR) polymerase chain reaction which indicated that: Deduce of $\mathrm{Ca}^{++}, \mathrm{Mg}^{++}$ , $\mathrm{Na}^{+}, \mathrm{K}^{+}$elements in citrus honey. Results were increase of Carniolan in the percentage of $\mathrm{Ca}^{++}$and $\mathrm{Mg}^{+++}$, mean reached $23.44,3.10$ (mg\%) and decreases in the Italian bee to reached 16.81, 2.01 (mg\%), respectively. And were reached of $\mathrm{Na}^{+}$and $\mathrm{K}^{+} 8.86,16.94-8,00$ 15.53 ( $m$ Eq\%) of Italian and Carniolan bee, respectively. Increase of Carniolan bee of enzymes activities $\alpha$ and $\beta$ esterase, Invertase, Trehalase and Amylase in reproduced citrus honey more than Italian bee. Increase of sugars (Glucose and Fructose) in field bee haemolymph in both strains bee. Increase of enzyme activities Invertase, Trehalase and Amylase in field bees haemolymph in both Carniolan and Italian strains. And not different between both strains in DNA analysis.
\end{abstract}

Key words: Strains, Biochemical analysis, Enzymes activity-DNA analysis - (PCR) polymerase chain reaction, haemolymph, physiological characteristics, components.

\section{INTRODUCTION}

Many studies on honey were carried out by Scientists with special Reference to it's composition (white et al., 1962), (White and winters, 1989, white, (1979), AOAC, (1980), Siddique, (1970), Donner, (1977), Farghally, (1980) and El-Sherbiny and Rizk, 1979). Honey as it is found in the hive is a truly remarkable material prepared by the bees from the natural sugar solutions we know as nectar, it is changed from an easily spoiled, then, sweet liquid to a stable high density, high energy, food. By inverting the sugar in the nectar, the bee mereases the attainable density of the final product, and thus raises efficiency of the process in terms of caloric density. The chemical composition of honey is complex and its contents of individual constituents are very considerably (Hassan, 1985). Honey, is also known to contain a large numbers of polyphenols, flavonoides and antioxidants (Blasa et al., 2006). And honey is also known to contain sugar, pollen grains, pigments, Minerals, Enzymes and water (Abd-El-Naby and Zidan (2014).

From these points of view this research was conducted to know and determined physiological characters of citrus honey and Carniolan, Italian bees for biochemical analysis component and DNA analysis of Carniolan and Italian bees strains (Besnard et al. (2001), Abdelrazik et al. (2007).

\section{MATERIALS AND METHODS}

Citrus honey and bee workers of Carniolan and Italian strains. All samples (3 replicates/ sample) at Menoufia Governorate were collected from apiary in Sadat Town during spring season from period March April 2015/2016. All samples were analyzed at the Chemical microanalysis Unit, physiology Res. Dep., plant protection Res. Institute Giza, Egypt. For the following properties: 


\section{Apparatus:}

Insects were homogenized for biochemical analysis in a chilled glass Teflon tissue homogenizer (ST - 2 Mechanic-Preczyina , Poland ). After homogenation, supernatants were kept in a deep freezer at $-20^{\circ} \mathrm{C}$ till use for biochemical assays. Double beam ultraviolet / visible spectrophotometer (spectronic 1201, Milton Roy Co. ,USA ) was used to measure absorbance of colored substances or metabolic compounds .

\section{Preparation of insects for analysis:}

The insects were homogenized in distilled water $(50 \mathrm{mg} / 1 \mathrm{ml})$. Homogenates were centrifuged at $8000 \mathrm{rpm}$ for $15 \mathrm{~min}$ at $5^{\circ} \mathrm{C}$ in a refrigerated centrifuge. The deposits were discarded and the supernatants were kept in a deep freezer till use.

\section{Honey preparation:}

Weight accurately a representative quantity of about $5 \mathrm{~g}$ of the homogenous honey sample, dissolve in distilled water and dilute to $100 \mathrm{ml}$ in a caliberation flask (diluted honey solution ).

\section{Calcium $\left(\mathrm{Ca}^{++}\right)$determination:}

Calcium ion was determined using Bioanalytics kit (email: bioanlab@bellsouth.net. Palm city, USA). Calcium reacts with cresophthalein in an alkaline medium to form a colored complex. The color developed has a maximum absorbance at $570 \mathrm{~nm}$ and is proportional to the calcium concentration in ath sample. Measurement was against reagent blank and compared to calcium standard $(10 \mathrm{mg} / \mathrm{dl})$.

\section{Magnesium $\left(\mathrm{Mg}^{+++}\right)$determination:}

Determination of $\mathrm{Mg}$ by the xylidyl blue method was followed using Quimica Clinica Aplicada S.A. kit (Spain). In an alkaline medium, the magnesium ions of the sample will produce a colored complex with xylidyl blue. Color intensity is directly proportional to the magnesium ions concentration. Ten microliters of the sample were added to $1 \mathrm{ml}$ reagent $(0.1 \mathrm{mM}$ xylidyl blue; $0.3 \mathrm{mM}$ Tris buffer $\mathrm{pH} 11 ; 50 \mathrm{uM}$ Glycoletherdiamine -N, $\mathrm{N}, \mathrm{N} \mathrm{N}$-tetraacetic acid as a chelating agent) for $10 \mathrm{~min}$ at room temperature (20$25^{\circ} \mathrm{C}$ ). The Color produced was read at 520 $\mathrm{nm}$ against standard $(4 \mathrm{mg} / \mathrm{dl})$.

\section{$\mathrm{Na}^{+}$and $\mathrm{K}^{+}$determination:}

lons measurements were made on a radiometer FLM3 falme photometer as described by Amin and El-Halafawy (2002). The standard solution contained sodium chloride $(14 \pm 1.4 \mathrm{mmol} / \mathrm{L})$ and potassium chloride $(5 \pm 0.5 \mathrm{~m} \mathrm{~mol} / \mathrm{L})$ stored at room temperature $\left(25^{\circ} \mathrm{C}\right)$. Zero adjustment was against blank prepared by adding $5 \mathrm{ml}$ of concentrated lithium chloride $(300 \pm 5 \mathrm{~m}$ $\mathrm{mol} / \mathrm{L}$ ) to $500 \mathrm{ml}$ of distilled water.

\section{Determination of phosphates activity:}

Acid and alkaline phosphatases were determined according to the method described by Powell and Smith (1954). In this method, the phenol released by enzymatic hydrolysis of disodium phenylphosphate reacts with 4aminoantipyrine, and by the addition of potassium ferricyanide, the characteristic brown color is produced.

\section{Determination of Alpha and Beta esterases activity:}

Alpha esterases ( $\alpha$-esterases) and beta esterases ( $\beta$-esterases) were determined according to Van Asperen (1962) using $\alpha$ naphthyl acetate or $\beta$-naphthyl acetate as substrates, respectively. The developed color was read at 600 or $555 \mathrm{~nm}$ for $\alpha$ - and $\beta$-naphthol produced from hydrolysis of the substrate, respectively.

\section{Determination of Invertase , Trehalase and Amylase activities:}

Digestive enzymes were determined according to the method described by Ishaaya and Swirski (1976) using trehalose , sucrose, and soluble starch as substrates 
for trehalase, invertase and $\alpha$-amylase, respectively.

Generally, $20 \mu \mathrm{l}$ of diluted enzyme solution was incubated for $10 \mathrm{~min}$ at $30{ }^{\circ} \mathrm{C}$ with $250 \mu \mathrm{l} 4 \%$ sucrose solution and $230 \mu \mathrm{l}$ phosphate buffer $(\mathrm{pH}, 5.4,0.1 \mathrm{M})$. The reaction was stopped by adding $250 \mu$ DNS reagent to each tube in boiling water for 5 min. Samples were cooled, diluted with 2.5 $\mathrm{ml} \mathrm{H}_{2} \mathrm{O}$, and read at $550 \mathrm{~nm}$.

\section{Glucose determination:}

Glucose is widely distributed simple sugar with an active aldhyde group. Estimation of glucose by glucose oxidase gives the true glucose concentration eliminating the interference by other reducing sugars.

Glucose was assayed using Stanbio kit (Stanbio Laboratory, Inc. 2930 East Houston street, San Antonio, Texas 78202). Glucose oxidase catalysesthe oxidation of alpha-Dglucose to D-glucono-1,5 lacyone (gluconic acid) with the formation of hydrogen peroxide. The oxygen liberated from hydrogen peroxide by peroxidase reacts with the O- dianisidine and oxidises it to a red chromophore product that read at 500 $\mathrm{nm}$ by spectophtometer, and the optical density compared by standard (cone. 100 $\mathrm{mg} \%$ ) to obtain the results, Bogdanov and Baumann (1988).

\section{Fructose determination:}

Determination of fructose was done using Biodiagnostic kit (info@biodiagnosvtic.com). Fructose forms a pink color when heated with resorcinol in the prescence of hydrochloric acid, which can be directly measured photometrically at 495 $\mathrm{nm}$. Fivety microliters of sample were added to $0.5 \mathrm{ml}$ of trichloroacetic acid (1 M). Mix well. Let stand for $10 \mathrm{~min}$. Centrifuge at $3000 \mathrm{rpm}$ for $10 \mathrm{~min}$. Add $50 \mu \mathrm{l}$ of the supernatant to $100 \mu \mathrm{l}$ of resorcinol $(9 \mathrm{mM})$ and $1 \mathrm{ml}$ of $\mathrm{HCL}(9 \mathrm{M})$. Mix well, place into a boiling water bath for exactly $5 \mathrm{~min}$. Allow to cool in cold water. Then measure the absorbance against reagent blank and compared to that of standard fructose (300 $\mathrm{mg} / \mathrm{dl}$ ), Bogdanov and Baumann (1988).

Analysis of DNA from haemolymph of bee workers both strains of Carniolan and Italian using bead-beaing method (AbdelRazik et al., 2007).

PCR reactions $(25 \mu \mathrm{l})$ with primers were contained 25 to $50 \mathrm{mg}$ of DNA $(1 \mu \mathrm{l}$ of diluted DNA), $105 \mu \mathrm{l}$ of $10 x$ rection buffer, $200 \mu$ MdNTP $_{s}$ (sigmas chemical Co. St. Louis), $0.8 \mu \mathrm{M}$ primer. Primers were screened against DNA from haemolymph. Tested primers that produced strong, reproduceible PCR products (bands) of both strains. The reproducibility of the RAPD markers was tested by performing PCR reactions with different concentrations (20$200 \mu \mathrm{g} / \mu \mathrm{l}$ ) of DNA template, with at least three independent DNA extractions from the same sample (Besnard et al., 2001). Analysis of DNA of both Carniolan an Italian bees was conducted at the Insect biotechnology and Molecular biology unit, plant protection Res. Institute.

\section{Statistical analysis:}

Means bearing different subscripts (within column) are significantly different $(p<0.01$, ANOVA, Duncan's, 1955 multiple rang test).

\section{RESULTS AND DISCUSSION \\ The determination of some minerals in citrus honey:}

Data in Table (1) reveal the mean percentage of calcium reached 16.81and $23.44(\mathrm{mg} \%)$ at Italian and Carniolan bee, respectively.

While the mean of Magnesium (mg\%), sodium and potassium (mEq\%) reached $2.01,3.10-8.86,8.00-16.94,15.53(\%)$ at Italian and Carniolan bee, respectively.

The increased the mean percentage of calcium and potassium in Carniolan and Italian bees but not determined of house and field bees from both strains for $\mathrm{Ca}^{++}, \mathrm{Mg}^{+++}$ , $\mathrm{Na}^{+}$and $\mathrm{K}^{+}$. 
Table (1): The mean biochemical analysis components (Minerals/honey) of Carniolan and Italian bees strains

\begin{tabular}{|l|c|c|}
\hline \multicolumn{1}{|c|}{ Minerals } & $\begin{array}{c}\text { Carniolan bee } \pm \text { SD } \\
\text { (Citrus honey) }\end{array}$ & $\begin{array}{c}\text { Italian bee } \pm \text { SD } \\
\text { (Citrus honey) }\end{array}$ \\
\hline Calcium $(\mathrm{mg} \%)$ & $23.44 \pm 2.37 \mathrm{a}$ & $16.81 \pm 1.16 \mathrm{a}$ \\
\hline Magnesium $(\mathrm{mg} \%)$ & $3.10 \pm 0.27 \mathrm{a}$ & $2.01 \pm 0.21 \mathrm{~b}$ \\
\hline Sodium (mEq\%) & $8.00 \pm 0.26 \mathrm{a}$ & $8.86 \pm 0.3 \mathrm{a}$ \\
\hline Potassium (mEq\%) & $15.53 \pm 0.21 \mathrm{a}$ & $16.94 \pm 1.56 \mathrm{a}$ \\
\hline
\end{tabular}

Means bearing different subscripts (within column) are significantly different $(p<0.01$, ANOVA, Duncan's multiple range test)

\section{The determination of enzymes activities: Alkalin phosphatase enzyme:}

Data in Table (2) show that the average of Alkaline phosphates activities reached 1315.7, 1372.0, 1539.3 and $1220.3\left(\mathrm{Ux} \times 0^{3} /\right.$ insect (worker)) in house bees and field bees Carniolan and Italian strain, respectively.

The highest activity of alkaline phosphatose enzyme in haemolymph of hose bees of Italian strain more than field bees. And house, field bees of Carniolan strain. Alkaline phosphatose in honey of both strains was Nil because bee honey acidity ( $\mathrm{pH}=3.9-4.1)$ Table (3).

\section{Alpha esterase enzyme:}

Data presented in Table (2) show that mean activity of Alpha esterase enzyme reached 97.67, 90.70, 139.00 and 154.00 ( $\mathrm{gg} \quad \alpha$-naphthol/min/insect (worker)) in Carniolan and Italian (house, field bees), respectively.

And the mean reached 2388.00 and 2366.33 ( $\mu \mathrm{g} \mathrm{\alpha -naphthol} / \mathrm{min} / \mathrm{ml}$ ) in Carniolan and Italian honey, respectively.

The highest activity of Alpha esterase enzyme in haemolymph of Italian bees and highest in honey of Carniolan bees. Table (3).

\section{Beta esterase enzyme:}

As shown in Table (2) mean activity of Beta esterase enzyme reached 86.33, $79.70, \quad 112,70$ and 171.70 ( $\mu \mathrm{g}-\beta$ naphthol/min./insect (worker)) in Carniolan and Italian (house, field bees), respectively.

And the mean reached 2201.70 and $2011.30(\mu \mathrm{g}-\beta$-naphthol $/ \mathrm{min} . / \mathrm{ml})$ in Carniolan and Italian honey respectively.

The highest activity of Beta esterase enzyme in haemolymph of Italian bees and highest activity in honey of Carniolan bees. Table (3).

\section{Invertase enzyme:}

Data in Table (2) mean activity of invertase enzyme reached 499.33, 701.70, 539.33 and 823.00 ( $\mu \mathrm{g}$ glucose/min./insect) in Carniolan and Italian (house, field bees) respectively.

And the mean reached 2316.70 and 1410.00 ( $\mu \mathrm{g}$ glucose $/ \mathrm{min} . / \mathrm{ml}$ ) in Carniolan and Italian honey respectively. Table (3).

The highest activity of invertase enzyme in haemolymph of field bees Carniolan and Italian bees Table (2) and highest activity in honey of Carniolan bees more than of Italian honey (Table 3). 
Table (2): The mean biochemical analysis components (enzymes/bees) of Carniolan and Italian bees strains

\begin{tabular}{|l|c|c|c|c|}
\hline \multirow{2}{*}{\multicolumn{1}{|c|}{ Treatments }} & \multicolumn{2}{c|}{ Carniolan bee \pm SD } & \multicolumn{2}{c|}{ Italian bee \pm SD } \\
\cline { 2 - 5 } & House bees & Field bees & House bees & Field bees \\
\hline Enzymes: & & & & \\
\hline Alkaline Phosphatase & $1315.70 \pm 20.5 \mathrm{~b}$ & $1372.00 \pm 30.1 \mathrm{ab}$ & $1539.30 \pm 56.5 \mathrm{a}$ & $1220.30 \pm 118 \mathrm{~b}$ \\
\hline a-esterase & $97.67 \pm 3.51 \mathrm{c}$ & $90.70 \pm 4.0 \mathrm{c}$ & $139.00 \pm 4.35 \mathrm{~b}$ & $154.00 \pm 7.9 \mathrm{a}$ \\
\hline B-esterase & $86.33 \pm 3.21 \mathrm{c}$ & $79.70 \pm 3.2 \mathrm{c}$ & $112.70 \pm 7.37 \mathrm{~b}$ & $171.70 \pm 7.63 \mathrm{a}$ \\
\hline Invertase & $499.33 \pm 14 \mathrm{c}$ & $701.70 \pm 7.6 \mathrm{~b}$ & $539.33 \pm 10.5 \mathrm{c}$ & $823.00 \pm 25.2 \mathrm{a}$ \\
\hline Trehalase & $154.33 \pm 8.14 \mathrm{~b}$ & $155.33 \pm 13.6 \mathrm{~b}$ & $165.33 \pm 8.5 \mathrm{~b}$ & $440.00 \pm 26.8 \mathrm{a}$ \\
\hline Amylase & $140.70 \pm 4.0 \mathrm{c}$ & $184.00 \pm 15 \mathrm{~b}$ & $136.33 \pm 4.16 \mathrm{c}$ & $399.33 \pm 11 \mathrm{a}$ \\
\hline
\end{tabular}

Alkaline Phosphatase $=\mathrm{U} \times 10^{3} /$ worker)

$\alpha$-esterase $=\mu \mathrm{g} \alpha$-naphthol $/ \mathrm{min} /$ worker

$\beta$-esterase $=\mu \mathrm{g} \beta$-naphthol $/ \mathrm{min} /$ worker

Invertase + Trehalase + Amylase $=\mu \mathrm{g}$ glucose $/ \mathrm{min} /$ worker

Means bearing different subscripts (within column) are significantly different $(p<0.01$, ANOVA, Duncan's multiple range test)

Table (3): The mean biochemical analysis components (enzymes/honey) of Carniolan and Italian bees strains

\begin{tabular}{|c|c|c|}
\hline Treatments & $\begin{array}{c}\text { Carniolan bee } \pm S D \\
\text { (Citrus honey) }\end{array}$ & $\begin{array}{l}\text { Italian bee } \pm S D \\
\text { (Citrus honey) }\end{array}$ \\
\hline $\begin{array}{l}\text { Enzymes: } \\
\text { Alkaline Phosphatase }\end{array}$ & Nil & Nil \\
\hline$\alpha$-esterase & $\begin{array}{c}2388.0 \pm 164 a \\
\mu g \text { a-naphthol } / \mathrm{min} / \mathrm{ml} .\end{array}$ & $\begin{array}{c}2366.33 \pm 138 a \\
\mu g \text { a-naphthol } / \mathrm{min} / \mathrm{ml} \text {. }\end{array}$ \\
\hline$\beta$-esterase & $\begin{array}{c}2201.7 \pm 93 \mathrm{a} \\
\mu \mathrm{g} \beta \text {-naphthol } / \mathrm{min} / \mathrm{ml} .\end{array}$ & $\begin{array}{c}2011.3 \pm 127 \mathrm{a} \\
\mu \mathrm{g} \beta \text {-naphthol } / \mathrm{min} / \mathrm{ml} .\end{array}$ \\
\hline Invertase & $\begin{array}{c}2316.7 \pm 125 \mathrm{a} \\
\mu \mathrm{g} \text { glucose } / \mathrm{min} / \mathrm{ml} .\end{array}$ & $\begin{array}{c}1410.0 \pm 147 \mathrm{~b} \\
\mu \mathrm{g} \text { glucose } / \mathrm{min} / \mathrm{ml} \text {. }\end{array}$ \\
\hline Trehalase & $\begin{array}{c}2101.7 \pm 60 \mathrm{a} \\
\mu \mathrm{g} \text { glucose } / \mathrm{min} / \mathrm{ml} .\end{array}$ & $\begin{array}{c}2020.0 \pm 72 a \\
\mu g \text { glucose } / \mathrm{min} / \mathrm{ml} .\end{array}$ \\
\hline Amylase & $\begin{array}{c}1985.7 \pm 106 \mathrm{a} \\
\mu \mathrm{g} \text { glucose } / \mathrm{min} / \mathrm{ml} .\end{array}$ & $\begin{array}{c}826.33 \pm 66 b \\
\mu \mathrm{g} \text { glucose } / \mathrm{min} / \mathrm{ml} \text {. }\end{array}$ \\
\hline
\end{tabular}

Means bearing different subscripts (within column) are significantly different $(p<0.01$, ANOVA, Duncan's multiple range test) 


\section{Trehalase enzyme:}

Data in Table (2) mean activity of Trehalase enzyme reached 154.33, 155.33, 165.33 and 440.00 ( $\mu \mathrm{g}$ glucose $/ \mathrm{min} /$ insect) in Carniolan and Italian honey (house, field bees), respectively. And the mean reached 2101.7 and $2020.0(\mu \mathrm{g}$ glucose $/ \mathrm{min} / \mathrm{ml}$.) in Carniolan and Italian honey, respectively. The highest activity of Trehalase enzyme in haemolymph of field bees Italian and the highest activity of Trehalase in honey of Carniolan bees. Table (3)

\section{Amylase enzyme:}

As shown in Table (2) mean activity of Amylase enzyme reached 140.7, 184.00, 136.33 and 399.33 ( $\mu \mathrm{g}$ glucose $/ \mathrm{min} / \mathrm{insect}$ ) in Carniolan and Italian (house, field bees), respectively.

And the mean reached 1985.7 and 826.33 ( $\mu \mathrm{g}$ glucose $/ \mathrm{min} / \mathrm{ml}$ ) in Carniolan and Italian honey, respectively (Table 3). The highest activity of Amylase enzyme in haemolymph of field Italian bees. (table 2).

And highest enzyme activity in honey of Carniolan bees. More than Italian honey table (3).

The main digestive enzymes of carbohydrates present in the alimentary track of adult bees has been studied. The $\alpha-$ amylase that hydrolysis starch contained in pollen grains (Ohashi et al., 1999).

\section{The determination of Glucose Sugar:}

As shown in table (4) mean reached of Glucose sugar were 323.33, 1084.66, 311.00 and 2305.33 ( $\mu \mathrm{g} / \mathrm{insect}$ ) in Carniolan and Italian (house, field bees), respectively.

And the mean reached 27.13 and 32.43 (gm \%) in Carniolan and Italian honey, respectively (Table 5). The highest concentration of glucose sugar in haemolymph of field bees in Carniolan and Italian bees (Table 4) and significant between of glucose sugar in honey of Carniolan and Italian bees. Sugars are degraded into glucose and fructose by digestive enzymes in the alimentary tract. The carbohydrate economy of adult bees is well understood, especially the distribution and sugar concentration in tissues. (Panzenböch and Crailsheim, 1977).

Trehalose is the main sugar found in haemolymph of honeybee. Its concentration is very high and varies from $2 \mathrm{mg} / \mathrm{ml}$. to 40 $\mathrm{mg} / \mathrm{ml}$. (Blatt and Roces 2001). Other sugars found in the haemolymph are glucose and fructose. Their concentrations are relatively low: $15 \mu \mathrm{g} / \mathrm{l}$ and $7 \mu \mathrm{g} / \mathrm{ml}$ for glucose and fructose, respectively (Leta et al. 1996).

\section{The determination of fructose sugar:}

Data in Table (4) mean reached of fructose sugar were 275.33, 611.66, 310.00 and 925.66 ( $\mu \mathrm{g} / \mathrm{insect})$ in Carniolan and Italian (house, field bees), respectively. And the mean reached 38.17 and 28.88 (gm\%) in Carniolan and Italian honey, respectively (Table 5). The highest concentration of fructose sugar in haemolymph of field bees in Italian bees more than Carniolan bees and the highest concentration of fructose sugar in honey of Carniolan bees more than Italian honey. Generally the mean of biochemical analysis components of Carniolan and Italian honey bee strains of minerals, enzymes and sugars in citrus honey and haemolymph for bees from both strains (Table 6).

\section{DNA analysis on Carniolan and Italian bees strains}

As shown in Fig (1) show results of sequence of DNA for strains using PCR (Polymers Chain Reaction) and bands for DNA genome. Upper MW (Molecular Weights) had upper bands and lower molecular weights had lower bands. This analysis was obtained by primer Light bands (results (DNA) on gel image. DNA was not different in the two samples of strains. 
Table (4): The mean biochemical analysis components (sugars/bees) of Carniolan and Italian bees strains

\begin{tabular}{|l|l|l|l|l|}
\hline \multirow{2}{*}{ Treatments } & \multicolumn{2}{|c|}{$\begin{array}{c}\text { Carniolan bee } \pm \text { SD } \\
\text { strain }\end{array}$} & \multicolumn{2}{c|}{$\begin{array}{c}\text { Italian bee } \pm \text { SD } \\
\text { strain }\end{array}$} \\
\cline { 2 - 5 } & House bees & Field bees & House bees & \multicolumn{1}{|c|}{ Field bees } \\
\hline Sugars in bees: & & & & \\
\hline Glucose $(\mu \mathrm{g} /$ worker $)$ & $323.33 \pm 10.4 \mathrm{c}$ & $1084.66 \pm 74 \mathrm{~b}$ & $311.00 \pm 8.9 \mathrm{c}$ & $2305.33+94.5 \mathrm{a}$ \\
\hline Fructose $(\mu \mathrm{g} /$ worker $)$ & $275.33 \pm 17.9 \mathrm{c}$ & $611.66 \pm 34.5 \mathrm{~b}$ & $310.00 \pm 11.1 \mathrm{c}$ & $925.66 \pm 65.7 \mathrm{a}$ \\
\hline
\end{tabular}

Means bearing different subscripts (within column) are significantly different $(p<0.01$, ANOVA, Duncan's multiple range test)

Table (5): The mean biochemical analysis components (sugars/honey) of Carniolan and Italian bees strains

\begin{tabular}{|l|c|c|}
\hline \multicolumn{1}{|c|}{ Treatments } & $\begin{array}{c}\text { Carniolan bee } \pm \text { SD } \\
\text { (Citrus honey) }\end{array}$ & $\begin{array}{c}\text { Italian bee } \pm \text { SD } \\
\text { (Citrus honey) }\end{array}$ \\
\hline Sugars in honey: & & $32.43 \pm 0.81 \mathrm{~b}$ \\
\hline Glucose (gm\%) & $27.13 \pm 0.96 \mathrm{a}$ & $28.88 \pm 0.96 \mathrm{~b}$ \\
\hline Fructose (gm\%) & $38.17 \pm 1.3 \mathrm{a}$ & \\
\hline
\end{tabular}

Means bearing different subscripts (within column) are significantly different $(p<0.01$, ANOVA, Duncan's multiple range test)

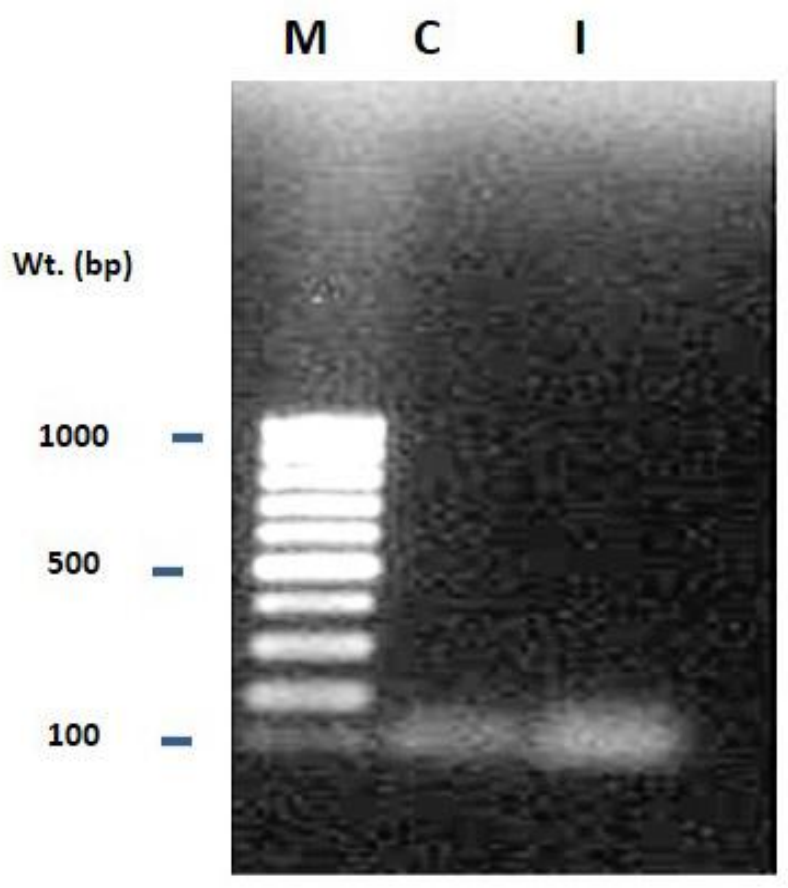

M: Represents 100 bp DNA Ladder

C: Represents the PCR product of the

Carniolan bees strain

I: Represents the PCR product of the Italian bees strain

Figure (1): Agarose gel $0.8 \%$ of the amplified DNA samples with universal primers. 
Abou-Lila

Table (6): The mean biochemical analysis components of Carniolan and Italian bee strains.

\begin{tabular}{|c|c|c|c|c|}
\hline Treatments & House bees & Field bees & Citrus honey & Values \\
\hline \multicolumn{5}{|c|}{ Carniolan bee strain \pm SD } \\
\hline \multicolumn{5}{|c|}{ Minerals } \\
\hline Calcium $\left(\mathrm{Ca}^{++}\right)$ & \multirow{4}{*}{$\begin{array}{c}\text { not } \\
\text { determined }\end{array}$} & \multirow{4}{*}{$\begin{array}{c}\text { not } \\
\text { determined }\end{array}$} & $23.44 \pm 2.37 a$ & $\mathrm{mg} \%$ \\
\hline Magnesium $\mathrm{Mg}^{+++}$ & & & $3.10 \pm 0.27 a$ & $\mathrm{mg} \%$ \\
\hline Sodium $\left(\mathrm{Na}^{+}\right)$ & & & $8.00 \pm 0.26 \mathrm{a}$ & $\mathrm{mEq} \%$ \\
\hline Potassium $\left(\mathrm{K}^{+}\right)$ & & & $15.53 \pm 0.21 \mathrm{a}$ & $\mathrm{mEq} \%$ \\
\hline \multicolumn{5}{|c|}{ Enzymes } \\
\hline Alkaline phosphatase & $1315.70 \pm 20.5 b$ & $1372.00 \pm 30.1 \mathrm{ab}$ & Nil & Ux $10^{3} /$ worker \\
\hline a-esterase & $97.67 \pm 3.51 \mathrm{c}$ & $90.70 \pm 4.0 \mathrm{c}$ & $2388.0 \pm 164 a$ & * \\
\hline$\beta$-esterase & $86.33 \pm 3.21 \mathrm{c}$ & $79.70 \pm 3.2 c$ & $2201.7 \pm 93 a$ & ** \\
\hline Invertase & $499.33 \pm 14 c$ & $701.70 \pm 7.6 \mathrm{~b}$ & $2316.7 \pm 125 a$ & $* * *$ \\
\hline Trehalase & $154.33 \pm 8.14 b$ & $155.33 \pm 13.6 b$ & $2101.7 \pm 60 a$ & $* * *$ \\
\hline \multirow[t]{2}{*}{ Amylase } & $140.70 \pm 4.0 \mathrm{c}$ & $184.00 \pm 15 b$ & $1985.7 \pm 106 a$ & $* * *$ \\
\hline & & Sugars & & \\
\hline Glucose & $323.33 \pm 10.4 \mathrm{c}$ & $1084.66 \pm 74 b$ & $27.13 \pm 0.96 a$ & $* \star * *$ \\
\hline Fructose & $275.33 \pm 17.9 \mathrm{c}$ & $611.66 \pm 34.5 b$ & $38.17 \pm 1.3 \mathrm{a}$ & $* * * *$ \\
\hline \multicolumn{5}{|c|}{ Italian bee strain \pm SD } \\
\hline Treatments & House bees & Field bees & Citrus honey & Values \\
\hline \multicolumn{5}{|c|}{ Minerals } \\
\hline Calcium $\left(\mathrm{Ca}^{++}\right)$ & \multirow{4}{*}{$\begin{array}{c}\text { not } \\
\text { determined }\end{array}$} & \multirow{4}{*}{$\begin{array}{c}\text { not } \\
\text { determined }\end{array}$} & $16.81 \pm 1.16 \mathrm{a}$ & $\mathrm{mg} \%$ \\
\hline Magnesium Mg ${ }^{+++}$ & & & $2.01 \pm 0.21 \mathrm{~b}$ & $\mathrm{mg} \%$ \\
\hline Sodium $\left(\mathrm{Na}^{+}\right)$ & & & $8.86 \pm 0.3 a$ & $\mathrm{mEq} \%$ \\
\hline Potassium $\left(\mathrm{K}^{+}\right)$ & & & $16.94 \pm 1.56 \mathrm{a}$ & $\mathrm{mEq} \%$ \\
\hline \multicolumn{5}{|c|}{ Enzymes } \\
\hline Alkaline phosphatase & $1539.30 \pm 56.5 a$ & $1220.30 \pm 118 b$ & Nil & Ux103/worker \\
\hline a-esterase & $139.00 \pm 4.35 \mathrm{~b}$ & $154.00 \pm 7.9 \mathrm{a}$ & $2366.33 \pm 138 a$ & ${ }^{*}$ \\
\hline$\beta$-esterase & $112.70 \pm 7.37 \mathrm{~b}$ & $171.70 \pm 7.63 a$ & $2011.3 \pm 127 a$ & $* *$ \\
\hline Invertase & $539.33 \pm 10.5 \mathrm{c}$ & $823.00 \pm 25.2 a$ & $1410.0 \pm 147 \mathrm{~b}$ & $* * \star$ \\
\hline Trehalase & $165.33 \pm 8.5 b$ & $440.00 \pm 26.8 \mathrm{a}$ & $2020.0 \pm 72 a$ & $* * *$ \\
\hline Amylase & $136.33 \pm 4.16 \mathrm{c}$ & $399.33 \pm 11 a$ & $826.33 \pm 66 b$ & $* * *$ \\
\hline \multicolumn{5}{|c|}{ Sugars } \\
\hline Glucose & $311.00 \pm 8.9 c$ & $2305.33+94.5 a$ & $32.43 \pm 0.81 \mathrm{~b}$ & $* * * *$ \\
\hline Fructose & $310.00 \pm 11.1 \mathrm{c}$ & $925.66 \pm 65.7 a$ & $28.88 \pm 0.96 b$ & $* * * *$ \\
\hline
\end{tabular}

Means bearing different subscripts (within column) are significantly different $(p<0.01$, ANOVA, Duncan's multiple range test)

* $\alpha$-esterase values in Bee $=\mu \mathrm{g} \alpha$-naphthol $/ \mathrm{min} /$ worker

${ }^{*} \alpha$-esterase values in Honey $=\mu \mathrm{g} \alpha$-naphthol $/ \mathrm{min} / \mathrm{mil}$

** $\beta$-esterase values in Bee $=\mu \mathrm{g} \beta$-naphthol $/ \mathrm{min} /$ worker

** $\beta$-esterase values in Honey $=\mu \mathrm{g} \beta$-naphthol $/ \mathrm{min} / \mathrm{mil}$

${ }^{* * *}$ Invertase + Trehalase + Amylase in Bee $=\mu \mathrm{g}$ glucose $/ \mathrm{min} /$ worker ${ }^{* * *}$ Invertase + Trehalase + Amylase in Honey $=\mu \mathrm{g}$ glucose $/ \mathrm{min} / \mathrm{mil}$. ${ }^{* * \star *}$ Glucose + Fructose .

$$
\text { in Bee }=\mu \mathrm{g} / \text { worker } \quad{ }^{* * * *} \text { Glucose }+ \text { Fructose. in Honey }=\mathrm{gm} \%
$$


Generally the statistical analysis of the obtained date show significant differences in the minerals, enzymes and sugars in citrus honey and haemolymph for bees between Carniolan and Italian honeybee colonies.

\section{REFERENCES}

Abdel-Naby. S. M. and E. W. Zidan (2014). Activity level of lactate dehydrogenase and $\beta$-glucosidase Enzymes in the honeybee colonies (Apis mellifera L.) with different feeding. Egypt. Acad. J. Biolog. Sci., 6(1): 93-100.

Abdelrazik, B.A., K. Fahmy and S. A. Ibrahim (2007). Biochemical and molecular identification of local isolates of Spirulina platensis and Spirulina maxima Egypt. J. Genet. Cytol., 36: 177190.

Amin, T. R. and N. A. El-Halafawy (2002). Sodium and potassium ions content of haemolymph in the normal and starved cotton leafworm, Spodoptera littoralis (Boisd.). Bull. Ent. Soc. Egypt, Econ. Ser., 28: 49-57.

Association of analytical chemists, AOAC (1980). Official methods of Analysis. Association of official Analytical chemists, Washington, D.C., U.S.A.

Banzenbock, U. and K. Crailsheim (1977). Glycogen in honeybee queens, workers and drones (Apis mellifera L. ). European Journal of Biochemistry 265: 127-133.

Besnard, G., P. Baradat, D. Chevalier, A. Tagmount and A. Berville (2001). Genetic differentiation in the olive complex (Olea europaea) revealed by RAPDs and RFLPs in the rRNA genes. Genet. Res. Crop Vol., 48: 165-182.

Blasa, M., M. Candiracci, A. Accorsi, M. P. Piacentini, M. C. Alpertini and E. Piatti (2006). Raw Millefiori honey is packed full of antioxidants. J. Food, Chemistry., 97: 217-222.
Blatt, J. and F. Roces (2001). Haemolymph sugar levels in Foraging honeybees (Apis Mellifera Carnica): Dependence on metabolic rate and in vivo measurement of maximal rates of trehalose synthesis. J. Experimental Biology 204: 2709-2716.

Bogdanov, M. and F.Baumann (1988). Determination of honey sugars with Hplc. Mitteiungen Aus. Dem. Gebiete. Der. Lebensmitteluntersu chung. Und. Hygiene. 79: 198-206.

Donner, L. W. (1977). The sugars of honey . a review-J.Sci. food Agric. Academic press. New York. pp. 297-301.

Duncan, D. B. (1955). Multiple range and Multiple f-test. Biometrics, 111: 1-24.

El-Sherbiny, G. A. and S. S. Rizk (1979): Chemical Composition of both clover and cotton honey produced in A.R.E. Egypt. J. Food Sci., 7 (1-2): 69-75.

Farghally, K. A. (1980). Studies on Egyptian honey M. Sc. Thesis. Faculty of Agriculture, University of Alexandria, Alex., Egypt.

Hassan, Mona I.M. (1985). Studies of food effect on of storage on some physical and chemical characteristics of bee honey. M.Sc. Thesis, Fac. Agric., Alex. Univ. Egypt.

Ishaaya, I. and E. Swirski (1976): Trehalase, invertase and amylase activities in the black scale, Saissetia oleae and heir relation to host adaptability. J. Insect. Physiol., 16: 1025-1029.

Leta, M. A., Gilbert, C. and R. A. Morse (1996). Levels of haemolymph sugars and body glycogen of honey bees (Apis mellifera 1.) from colonies preparing to swarm. J. of Insect Physiology 42: 239245.

Ohashi, K., Natori, S. and T. Kubo (1999). Expression of amylase and glucose oxidase in the hypopharyngeal gland with an age-dependent role change of the worker honeybee (Apis. mellifera European Journal of Biochemistry 265: 127-165. 


\section{Abou-Lila}

Powell, M. E. A. and M. J. H. Smith (1954). The determination of serum acid and alkaline phosphatase activity with 4aminoantipyrine.J. Clin. Pathol., 7: 245248.

Siddique, I.R. (1970): The sugar of honey Adv. Carbohydr. Chem. Biochem., (25): 285-309.

Van Asperen, K. (1962). A study of house fly esterase by means of sensitive colourimetric method. J. Insect. Physiol., 8: 401-416.
White, J. W. Jr. (1979). Methods for determining carbohydrates, hydroxymethylfurfural, and praline in honey. Collaborative study. J. of Association of official Analytical chemists. 62: 515-526.

White, J. W. Jr. and K. Winters (1989). Honey protein as internal standard for stable carbon isotope ratio detection of adulteration of honey. J. Assn. off Anal, chem.. 72 (60): 907-911.

White, J. W. Jr., M.I. Reithol, M.L.L. Subers and L. Kushnir (1962). Composition of American honey. U.S. Dep. Agric., Techbull. No. 1261.

\section{الخصائص الفسيولوجية لسلالتي نحل العلل الكرنيولي و الإيطالي و علاقة ذلك بمكونات عسل الموالح في مصر}

\section{أماني سعد مصطفى محمد أبو ليلة}

قسم بحوث النحل - معهد بحوث وقاية النباتات - مركز البحوث الزراعية - دقي - جيزة - مصر

يهدف البحث إلى التوصل لطريقة فسيولوجية للتمييز بين سلالتي نحل العسل الكرنيولي والإيطالي النقية و عسل الموالح الناتج منهها بالإضافة إلى تحليل الـ DNA للشغالات عن طريق تفاعل البلمرة النسلسلي (PCR) في فصل الربيع (مارس وابريل) عامي 2016/2015 بأحد مناحل مدينة السادات ، محافظة المنوفية وذلك لنقدير : 1 2- أنثطة إنزيمات : الفوسفاتيز (في وسط قلوي) - الفاوبيتا استنيريز - الانفرتيز - التريهاليز - الأميليز في الثـغالات الحاضنة والحقلية و العسل الناتج. 3- كميات سكري الجلوكوز و الفركتوز في الثغالات الحاضنة والحقلية و العل الناتج الناتج. 4- نحليل الـ DNA للثغالات بإجراء تفاعل البلمرة التسلسلي. وأوضحت النتائج وجود فروق معنوية واضحة بين السلالاتين كما يلى :

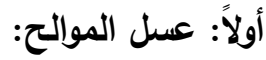

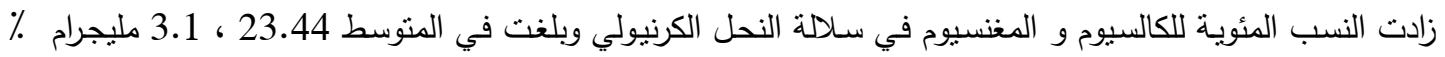
على التوالي و انخفضت في السلالة الإيطالي حيث بلغت 16.81 ، 2.01 مليجرام ٪ على النوالي، بينما تقاربت النسبة

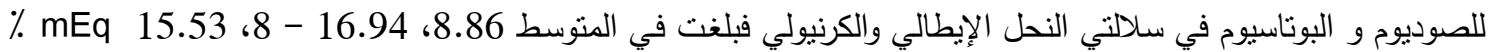

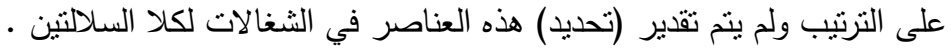




$$
\text { ثانياً: الإنزيمات والسكريات: }
$$

1- تفوقت سلالة النحل الكرنيولي في زيادة أنشطة أنزيمات الألفاو البيتا استيريز و الانفرتيز والتزيهاليز و الأميليز في

$$
\text { العسل الناتج عن السلالة الإيطالي. }
$$

2- زادت كميات سكري الجلوكوز والفركتوز في هيموليمف النحل الحقلي عن النحل الحاضن لكلا السلالتني.

3- زيادة نشاط أنزيمات الانفرتيز و النزيهاليز و الأميليز في دم النحل الحقلي عن النحل الحاضن لكلا السلالتنين. 4- تقوقت سلالة النحل الايطالى فى زيادة انشطة الانزيمات محل الدراسة فى هيموليف الثغالات عن السلالة الكرنيولى.

ثالثاً: تحليل الـ DNA

لم تظهر فروق واضحة عند تحليل الـDNA لعينات هيموليمف الثخالات لسلالتي النحل الكرنيولي والإيطالي ولذلك تحتاج

$$
\text { هذه النقطة لمزيد من الدراسة. }
$$

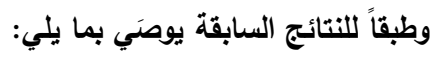

1- ضرورة الاهتمام والاستمرار في تربية كلا السلالتين في المناحل المصرية حيث تتفوق السلالة الكرنيولي في إنتاج العسل

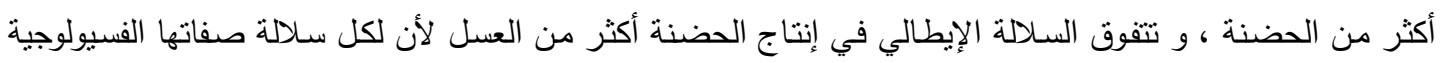

$$
\text { التي تميزها. }
$$

2- النوصية باستيراد كلا السلالتين النقية بطريقة رسمية منعاً لحدوث التربية الداخلية Inbreeding (تربية الأفارب) والتي تسبب انخفاض صفات نلك السلالات و قلة الإنتاج. 